
\title{
28 Research Suare \\ Effects of Livestock Grazing on Interannual Variation of Soil Methane Uptake in an Inner Mongolian Meadow Steppe
}

Ruirui Yan ( $\nabla$ yanruirui19790108@163.com )

Institute of Agricultural Resources and Regional Planning https://orcid.org/0000-0002-9400-1105

\section{Yu Zhang}

Michigan State University

Jiquan Chen

Institute of Botany, the Chinese Academy of Sciences

Linghao Li

Institute of Agricultural Resources and Regional Planning

Changliang Shao

Institute of Agricultural Resources and Regional Planning

Yuchun Yan

Institute of Agricultural Resources and Regional Planning

Xu Wang

Institute of Agricultural Resources and Regional Planning

xiaotao IV

Institute of Applied Ecology

Jinqiang Chen

Institute of Agricultural Resources and Regional Planning

Xiaoping Xin

Institute of Agricultural Resources and Regional Planning

\section{Research Article}

Keywords: Grassland soil. Grazing. Interannual change. Nitrogen. Rainfall. Biomass

Posted Date: November 5th, 2021

DOI: https://doi.org/10.21203/rs.3.rs-214632/v1

License: (1) (1) This work is licensed under a Creative Commons Attribution 4.0 International License.

Read Full License 


\section{Abstract}

Background and aims. This study aimed at identifying the effects of livestock grazing on interannual variation in soil $\mathrm{CH}_{4}$ uptake and underlying mechanisms in a meadow steppe ecosystem.

Methods. A multi-year grazing experiment subject to six stocking rates was conducted to quantify $\mathrm{CH}_{4}$ fluxes as well as the changes in driving factors: vegetation traits, soil physicochemical properties and climatic parameters. The closed static chamber technique and a gas chromatograph were used to measure methane fluxes. Multivariate regression analysis was performed to explore empirical relationships.

Results. With increasing stocking rate, the multi-year mean $\mathrm{CH}_{4}$ uptake rate decreased in a sigmoid curveshaped manner, with the threshold point appearing in the light grazing treatment. The interannual changes in soil $\mathrm{CH}_{4}$ uptake were highly dependent on stocking rate, with increasing, leveling and decreasing trends detected with increasing grazing intensity. Major factors affecting $\mathrm{CH}_{4}$ fluxes included vegetation traits, soil moisture, and soil nitrogen content, with the soil $\mathrm{NH}_{4}{ }^{+}-\mathrm{N}$ content assuming the most important role. However, predominant factors regulating interannual changes in $\mathrm{CH}_{4}$ uptake were rainfall, belowground biomass, and soil nitrogen regime.

Conclusions. The steppe ecosystem acted as a $\mathrm{CH}_{4}$ sink, irrespective of stocking rate and year. However, light grazing can be the threshold grazing intensity in terms of both the $\mathrm{CH}_{4}$ uptake potential and primary production in this steppe ecosystem. Our findings have important implications for further understanding magnitudes and regulations of $\mathrm{CH}_{4}$ uptake in grassland soils worldwide.

\section{Introduction}

Methane $\left(\mathrm{CH}_{4}\right)$ is the second most important anthropogenic greenhouse gas after carbon dioxide $\left(\mathrm{CO}_{2}\right)$, the global warming potential of which is roughly 28 times that of $\mathrm{CO}_{2}$ (IPCC 2013). Moreover, the atmospheric concentration of $\mathrm{CH}_{4}$ has been increasing at an alarming rate (ca. 1\% per annum) over the past several decades (Cicerone and Oremland 1988; Castaldi and Fierro 2005; Knox et al. 2019), although the increasing trend has slowed down ( $\mathrm{Li}$ 2021). A better understanding of the magnitude and trend over time for $\mathrm{CH}_{4}$ uptake/release, as well as the underlying mechanisms, is therefore of great significance (Han et al. 1999).

Two most significant sinks of atmospheric $\mathrm{CH}_{4}$, respectively, are abiotic oxidation by tropospheric hydroxyl radicals and consumption by aerobic methane oxidizing bacteria (MOB) in unsaturated soils (Dunfield, 2007). MOB, which are responsible for the only known biological removal of atmospheric $\mathrm{CH}_{4}$ (Dunfield, 2007; Tveit et al. 2019), can consume this greenhouse gas diffused into the soil to varying extents (Mosier et al. 1991), depending on the soil type with respect to soil moisture and aeration regimes, notably in diverse upland soils (Knief et al. 2003; Dunfield, 2007; Kolb, 2009). The structural and 
functional responses of $\mathrm{MOB}$ to changes in soil water are considered as crucial to explaining the magnitude and pattern of $\mathrm{CH}_{4}$ uptake (Bodelier et al. 2012; Tveit et al. 2019). Of all soil types, rangeland soils (especially temperate grassland soils) are the second largest sink for atmospheric $\mathrm{CH}_{4}$, next only to forest soils (Potter et al. 1996; Le Mer and Roger 2001; Kolb, 2009), due mainly to the large land area they cloth (White et al. 2000; Li et al. 2020).

Previous studies on grassland soils have shown that $\mathrm{CH}_{4}$ emission and uptake is site-specific and may be affected to varying degrees by management practices such as grazing, cultivation, and mowing, with grazing having the most substantial impact on the $\mathrm{CH}_{4}$ oxidation potential (Mosier et al. 1991, 1997, 2002; Del Grosso et al. 2000; Wang et al. 2009; Knox et al. 2019; Täumer et al. 2020). Relevant studies in temperate grasslands indicate that impacts of livestock grazing on soil $\mathrm{CH}_{4}$ uptake differ among grassland types and among communities of even the same type (Wang et al. 2005a; Liu et al. 2007, 2009; Chen et al. 2010; Geng et al. 2010). However, while some authors reported that grazing reduced soil $\mathrm{CH}_{4}$ uptake, others found that it led to increases or no change. A matter of fact is that grazing may reduce the growth of vegetation and litter storage that in turn would affect soil organic matter although SOM is not the primary food supply for MOB in most cases (Liu et al. 2007; Dunfield, 2007). Grazing at the same time can enhance soil evaporation and reduce soil moisture, thus affecting the physical environment of MOB. In addition, trampling by livestock can substantially compact the surface soil, which reduces diffusion rates of $\mathrm{CH}_{4}$ and oxygen. Unfortunately, most of the previous studies had been based on short-term observations (1-2 years; Liu et al. 2007, 2009) or conducted with only one stocking rate. As a result, one cannot: (1) assess long-term changes (including the potential legacy effects) and variation (e.g., intraand inter-annual variation) and thus (2) understand how grazing intensity may alter $\mathrm{CH}_{4}$ uptake differently.

The Hulun Buir steppe of Inner Mongolia is a typical temperate meadow steppe of the Eurasian steppe. This ecosystem is characterized by the highest plant species diversity, net primary production (NPP), and carbon sequestration potential among all steppe types in China. Here, livestock grazing is the most common way of grassland utilization. Because the soils are mostly fine-textured and xeric, with waterlogging occurring frequently in wet years, the meadow steppe is assumed to be unique and significant in terms of soil $\mathrm{CH}_{4}$ uptake. However, studies on soil $\mathrm{CH}_{4}$ dynamics of this steppe have been rarely carried out.

We conducted a 9-year field experiment to examine interannual changes and controls of soil $\mathrm{CH}_{4}$ uptake in response to variable stocking rates. Our study objectives were: (1) to examine interannual variation in soil $\mathrm{CH}_{4}$ uptake with respect to grazing intensity; and (2) to explore underlying mechanisms regulating $\mathrm{CH}_{4}$ uptake. Grazing usually may result in a series of changes in plant community traits and soil properties that may more or less mediate $\mathrm{CH}_{4}$ consumption by MOB. We selected canopy cover and height, litter biomass, aboveground biomass (AGB), belowground biomass (BGB), soil physical and microclimatic variables, soil microbial biomass (SMB), and soil nutrients as potential driving factors. We hypothesized that grazing may impose impacts on $\mathrm{CH}_{4}$ uptake by the soil via three approaches: (1) 
trampling that affects soil thermal and water regimes and compact the soil; (2) herbivory that may decrease litter input and carbohydrate allocation into the soil and subsequently may influence microbially-associated belowground processes; and (3) excretion of dung and urine on sward patches that may alter the soil chemical property thereof. All these may more or less influence the abundance and/or activity of MOB.

\section{Methods And Materials}

\section{Study site}

We conducted the field experiment in a Leymus chinensis meadow steppe ecosystem in the Hulun Buir steppe region, on the northeastern Inner Mongolia Plateau. In brief, the landform is dominated by hills, lowlands and table lands, with elevations mostly varying between 600 and $800 \mathrm{~m}$. The region has a temperate semi-humid climate, with an annual precipitation mostly between 350 and $400 \mathrm{~mm}$ that is highly seasonally variable. The mean annual air temperature spatially varies between -5 and $-2^{\circ} \mathrm{C}$, with a growing period of around 110 days. Chestnut soil is the predominant soil type, which corresponds to Castanozems in the soil taxonomic system of the FAO ( $\mathrm{Li}$ et al. 2020). The vegetation is composed of perennial grasses, sedges, and forbs, of which Leymus chinensis, Stipa baicalensis, Carex duriuscula, Galium verum, Bupleurum scorzonerifolium, and Filifolium sibiricum are the dominant species. There was a more than 100-year history of free-range livestock in the region, up until the 2000 s, after which prescribed ranging was implemented.

\section{Experimental design}

The field study plot is located at the Hulun Buir Grassland Ecosystem Observation and Research Station of the Chinese Academy of Agricultural Sciences (CAAS) (49²19'349"N, $119^{\circ} 56^{\prime} 5211^{\prime \prime} \mathrm{E} ; 670 \mathrm{~m}$ a.s.l.) (Fig. $1 S$ ). The steppe had been under heavy grazing since the $1980 \mathrm{~s}$. The grazing experiment with five stocking rates and one control unit was initiated in 2009 and has been continuously run till nowadays. Therefore, the control and all grazing treatments except the heavy grazing treatment $(0.69, \mathrm{G} 0.92)$ represented a stand sequence with variable degrees of recovery, while the heavy grazing treatment represented a stand under continuous long-term disturbance. The treatments were arranged in a randomized block design. Each treatment had three replicated units, with each unit being 5 ha in size. As such, a total of 18 units of six treatments were established. The units were separated by fences. The stocking rates were set as $0.00,0.23,0.34,0.46,0.69$, and $0.92 \mathrm{AU} \mathrm{ha}^{-1}$, where $1 \mathrm{AU}=500 \mathrm{~kg}$ of adult cattle, corresponding to $0,2,3,4,6$, and 8 young cattle (with $\sim 250-300 \mathrm{~kg}$ ) per unit (Fig. 1S). Grazing lasted for 120 days between June and September in each growing season from 2009 to 2018 . The grazing cattle were kept in each unit for $24 \mathrm{~h}$ each day during the entire grazing period.

\section{$\mathrm{CH}_{4}$ measurements and data analysis}

$\mathrm{CH}_{4}$ fluxes were measured in situ using the closed static chamber technique (Hutchinson and Mosier 1981). The static chambers were made of stainless steel and consisted of two parts: a square base 
frame $(0.5 \mathrm{~m} \times 0.5 \mathrm{~m} \times 0.1 \mathrm{~m})$ and a removable lid $(0.5 \mathrm{~m} \times 0.5 \mathrm{~m} \times 0.5 \mathrm{~m})$. Three frames were inserted in each unit at a soil depth of $10 \mathrm{~cm}$, and those remained fixed during the whole study period (2009-2018). The frames were only $3 \mathrm{~cm}$ above the ground, so they did not interfere with the movement of grazing cattle. Movable protection was used during sampling to prevent staff trampling from impacting vegetation and ground conditions. A fan powered by a $12 \mathrm{~V}$ battery was installed on the top wall of each static chamber to mix the air in the chamber. When placing the chambers on the frames, the vegetation within the frames was kept as intact as possible. $\mathrm{CH}_{4}$ in the chambers was collected using a $60 \mathrm{ml}$ airtight plastic syringe at 0, 10, 20 and 30 minute intervals for opaque chambers after manually closing the chamber between 9:00 to 11:00 h am. Our previous studies indicated that $\mathrm{CH}_{4}$ emission during the time interval of 9:00-11:00 in the morning is well representative of the average rate over a $24 \mathrm{~h}$ cycle (Wang et al. 2005b). Gas samples were pumped into $50 \mathrm{ml}$ airbags and sealed tightly. These bags were then transported to the lab within one week for $\mathrm{CH}_{4}$ concentration measurement using an Agilent 7890A series gas chromatograph (Agilent 7890A, Agilent Technologies, Ltd., Co., USA). $\mathrm{CH}_{4}$ fluxes were measured biweekly from June to September in 2010 and weekly in the following years. $\mathrm{CH}_{4}$ fluxes were calculated by least squares regression of concentrations over time and expressed as $\mu \mathrm{g} \mathrm{CH}_{4}-\mathrm{C} \mathrm{m}^{-2} \mathrm{~h}^{-1}$, after being corrected for air pressure, volume, and surface area.

The greenhouse gas $\mathrm{CH}_{4}$ flux was calculated from the concentration change over the sampling intervals by using the following expression:

$$
F=\rho \times V \times \frac{\Delta C}{\Delta t} \times \frac{1}{A}=D \times H \times \frac{\Delta C}{\Delta t} 1
$$

where $\mathrm{F}$ means gas flux ( $\left.\mathrm{mg} \mathrm{m}^{-2} \mathrm{~h}^{-1}\right)$; $\rho$ is the gas density inside the chamber $(\rho=P / R T$, $P$ is air pressure at the sampling site, $\mathrm{R}$ refers to the gas constant, and $\mathrm{T}$ is temperature inside the chamber); $\mathrm{V}$ is the

volume of the measuring chamber $\left(\mathrm{m}^{3}\right) ; \frac{\Delta C}{\Delta t}$ is the linear slope change of $\mathrm{CH}_{4}$ gas concentrations in the container during the sampling time; $V$ is the volume of measuring chamber, unit $\mathrm{m}^{3}$; $\mathrm{A}$ is the bottom area of the measuring chamber $\left(\mathrm{m}^{2}\right) ; \mathrm{H}$ is the height of chambers. A positive value for $\mathrm{F}$ means gas emission into the atmosphere from the soil, and a negative value means gas absorption from the atmosphere to the soil (Dong et al. 2000). The seasonal mean flux was calculated by averaging all flux measures during the sampling period. The cumulative (growing season of each year) flux rates were calculated by multiplying the average values by 120 days (i.e. the number of days between 1-June and 30-September).

\section{Vegetation and soil properties}

Five $1 \mathrm{~m} \times 1 \mathrm{~m}$ quadrats were randomly placed within each grazing unit in August of each year. The canopy height was derived in light of the individual shoot heights of all major species, with 5 randomly selected individuals per species being measured. A $1 \mathrm{~m} \times 1 \mathrm{~m}$ point frame with 100 crosshairs using a grid was used to measure canopy coverage. The aboveground vegetation was subsequently clipped to the ground, separated into living and dead materials, and dried at $65^{\circ} \mathrm{C}$ for $48 \mathrm{~h}$ to determine the aboveground biomass (AGB) and litter mass. Below-ground biomass (BGB) samples were taken at the 
same time at $10 \mathrm{~cm}$-interval soil depths of $0-60 \mathrm{~cm}$ by a $30 \mathrm{~cm} \times 30 \mathrm{~cm}$ cross-section, with three replications for each unit being sampled (Yan et al. 2016).

Soil samples of the top $10 \mathrm{~cm}$ layer were collected using a soil drill with an inner diameter of $5 \mathrm{~cm}$ from 10 random locations per unit in early August of each year, with the ten samples being mixed to get an average for each unit. The combined samples were divided into two parts. One part was immediately screened by a $2 \mathrm{~mm}$ soil sieve, so it was maintained fresh and intact for determining soil microbial biomass and carbon, nitrogen, ammonium nitrogen and nitrate nitrogen contents. The other part was wind-dried, crushed and passed through a $0.15 \mathrm{~mm}$ sieve and a $2 \mathrm{~mm}$ sieve, respectively, for analysing soil properties. Soil organic carbon (SOC) was measured by the dichromate oxidation method; total soil nitrogen (TN) was measured by semi-micro Kjeldahl determination (Bao 2000); soil available nitrogen (SAN) was measured using the distillation method (Bao 2000). Soil ammonium $\left(\mathrm{NH}_{4}{ }^{+} \mathrm{N}\right)$ and nitrate $\left(\mathrm{NO}_{3}{ }^{-} \mathrm{N}\right)$ contents were determined using a flow injection auto-analyser (Bao 2000); soil microbial biomass carbon (MBC) and microbial biomass nitrogen (MBN) was measured using the fumigationextraction method. Soil pH (in water) was determined by using the electrode method. The soil moisture (Ms) was measured by the oven-drying method, and soil bulk density (SBD) was measured with the ring knife method by oven-drying the soils at $105^{\circ} \mathrm{C}$ for 24 hours (Bao 2000). Soil temperature was measured daily by using portable thermometers in the early years and automatic datalog sets in later years. Zhang et al. (2021) offers a detailed description of the methods used concerning soil physicochemical parameters.

\section{Statistical analyses}

Mean $\mathrm{CH}_{4}$ uptake rates were calculated by arithmetically averaging individual flux values on a given sampling occasion. Differences in mean and seasonal cumulative $\mathrm{CH}_{4}$ uptake rates among treatments were determined by analysis of two-way ANOVAs followed by Duncan multiple range test, with effects of $p<0.05$ being significant. Because the effect of grazing differed among the study years, repeatedmeasures ANOVAs were applied to determine the main and interactive effects of measurement year and grazing intensity on $\mathrm{CH}_{4}$ uptake rate, respectively. Linear regression was used to determine the mean variation of $\mathrm{CH}_{4}$ uptake in response to variations in vegetation properties and soil parameters. All statistical analyses were carried out using the SPSS software package (v24.0, SPSS, Inc.). Concurrently measured biotic or abiotic variables were assumed to cause variations in $\mathrm{CH}_{4}$ uptake when the correlation was significant $(P<0.05)$.

\section{Results}

\section{$\mathrm{CH}_{4}$ uptake and grazing intensity}

The steppe ecosystem acted as a $\mathrm{CH}_{4}$ sink during the 9-year study period, irrespective of stocking rate and year (Fig. 1). $\mathrm{CH}_{4}$ uptake was the highest $\left(-84.15 \pm 5.31 \mu \mathrm{g} \mathrm{m}^{-2} \mathrm{~h}^{-1}\right)$ at no-grazing treatment 
(G0.00), albeit there was no significant difference $(P>0.05)$ from that of $G 0.23\left(-77.74 \pm 3.24 \mu \mathrm{g} \mathrm{m}^{-2} \mathrm{~h}^{-}\right.$ $\left.{ }^{1}\right)$. The remaining four treatments significantly reduced the $\mathrm{CH}_{4}$ uptake to $\left(-60.12 \pm 0.49 \mu \mathrm{g} \mathrm{m}^{-2} \mathrm{~h}^{-1}\right)$. Interestingly, we found no significant difference among these four treatments $(P>0.05)$. The long-term average $\mathrm{CH}_{4}$ uptake with stocking rate followed a clear sigmoid pattern (Fig. 1). However, when examined at annual scale, stocking rates had different effects on the $\mathrm{CH}_{4}$ uptake rate, depending on the study year (Fig. 2A). Overall, there were no significant differences in the $\mathrm{CH}_{4}$ uptake rate between the treatments in the first three study years (2010-2012). In contrast, significant negative effects at the highest stocking rate (G0.92) were detected in all the subsequent years, while with the exception of the lowest stocking rate (G0.23), all the other stocking rates showed significant negative effects in 3-4 of the following years (i.e., $\mathrm{CH}_{4}$ uptake significantly decreased with increasing stocking rate) (Fig. 2A). When a simple linear regression model was applied to the relationship, with the cumulative treatment years increasing, the slope of the regression line increased substantially until to the year 2014 after five years of grazing treatment, after which the slope remained relatively constant. For example, the slope of the regression line in 2010 and 2011 was similar at $-9.92 \mu \mathrm{g} \mathrm{m}^{-2} . \mathrm{h}^{-1}$. Year ${ }^{-1}$ and $-7.75 \mu \mathrm{g} \mathrm{m}^{-2} . \mathrm{h}^{-1}$. Year ${ }^{-1}$, respectively. This slope increased to $10.10 \mu \mathrm{g} \mathrm{m}^{-2} . \mathrm{h}^{-1}$. Year ${ }^{-1}$ in 2012 and $29.00 \mu \mathrm{g} \mathrm{m}^{-2} . \mathrm{h}^{-1}$. Year ${ }^{-1}$ in 2013. Starting in 2014, the slope appeared to level off at $36 \mu \mathrm{g} \mathrm{m}^{-2}$. $\mathrm{h}^{-1}$. Year ${ }^{-1}$ (Fig. 2B). It is worth noting that the variation among the treatments of the same year also changed over time during the 9-year study period (Fig. 3B). The variation among the treatments, as measured by confidence interval (CV), exhibits a logistical change with year, ranging from the lowest value (4.84\%) in 2010 to $24.93 \%$ in 2016.

\section{Interannual change in $\mathrm{CH}_{4}$ uptake}

We also examined our field data for interannual changes and variations (Fig. 3A, Fig. 4). The changes in $\mathrm{CH}_{4}$ uptake rate over time appear to depend on grazing intensity (Fig. 3A). Nevertheless, an obvious trend in this pattern occurred with increasing stocking rate. The interannual variation in the $\mathrm{CH}_{4}$ uptake rate show an obvious increasing trend under no-grazing (G0.00) and light grazing (G0.23) treatments, but this uptake shows no obvious increase at $\mathrm{G} 0.34$, and this increasing trend was shifted to a decreasing one under G0.46, G0.69 and G0.92. Interestingly, we found that the interannual variation (i.e., CV values) show a positive linear relationship with an increasing stocking rate (Fig. 4), which ranged from $13.63 \%$ under G0.00 to $27.98 \%$ under G0.92.

\section{Regulation of $\mathrm{CH}_{4}$ uptake}

By pooling all field data from 9 years and 6 grazing treatments, we detected significant positive relationships between $\mathrm{CH}_{4}$ uptake rate and major vegetation parameters, including canopy height, canopy cover, AGB, BGB, and litter biomass (Fig. 5). Of all the microclimatic and soil parameters, significant negative relationships between $\mathrm{CH}_{4}$ uptake rate and precipitation, soil moisture, and soil $\mathrm{NH}_{4}{ }^{+}-\mathrm{N}$ content were ascertained. However, significant positive relationships between $\mathrm{CH}_{4}$ uptake rate and soil organic carbon, total nitrogen, and microbial biomass nitrogen were found (Fig. 6). 
We performed forward stepwise regression analysis by including all potential biophysical variables as independent variables (Table 1). It appears that $\mathrm{CH}_{4}$ uptake under different grazing intensity can be confidently predicted by three dominant drivers at $R^{2}$ value of 0.75 for $G 0.92$ and $0.96 / 0.97$ at G0.23/G0.69. However, the three most significant independent variables, as well as their contributions, were not the same among treatments. For example, under the no-grazing (G0.00) and light grazing (G0.23) treatments, soil $\mathrm{NH}_{4}{ }^{+}-\mathrm{N}$ and belowground biomass were selected as the significant drivers for predicting $\mathrm{CH}_{4}$ uptake, whereas under $\mathrm{G} 0.34$ and $\mathrm{G} 0.46$, rainfall and soil available nitrogen (mainly $\mathrm{NH}_{4}{ }^{+}$ $\mathrm{N})$ became the major explanatory variables. For G0.69 and G0.92, total nitrogen, vegetal biomass, and soil moisture assumed major importance. 
Table 1

Multivariate linear regression models for predicting the annual $\mathrm{CH}_{4}$ uptake rate with biotic and abiotic variables under the six experimental treatments. Three most significant independent variables were selected and presented sequentially according to their contributions ranging $0-1$ in the parentheses. AGB: Aboveground biomass; BGB: Belowground biomass; TN: Soil total nitrogen; SAN: Soil available nitrogen; MBC: Microbial biomass carbon.

\begin{tabular}{|c|c|c|c|c|c|}
\hline Treatment & Stepwise regression equation & $\mathbf{F}$ & $\mathbf{P}$ & $\mathrm{R}^{2}$ & Contribution \\
\hline \multirow[t]{3}{*}{ G0.00 } & \multirow[t]{3}{*}{$\begin{array}{l}\mathrm{CH}_{4}=85.36-0.45 \mathrm{NH}_{4}^{+}-\mathrm{N}+0.021 \mathrm{BGB}+ \\
0.38 \text { Cover }\end{array}$} & \multirow[t]{3}{*}{11.62} & \multirow[t]{3}{*}{0.01} & \multirow[t]{3}{*}{0.88} & $\begin{array}{l}\mathrm{NH}_{4}^{+}-\mathrm{N} \\
(0.51)\end{array}$ \\
\hline & & & & & BGB (0.17) \\
\hline & & & & & Cover $(0.14)$ \\
\hline \multirow[t]{3}{*}{ G0.23 } & \multirow[t]{3}{*}{$\mathrm{CH}_{4}=92.68+0.04 \mathrm{BGB}-0.42 \mathrm{NH}_{4}{ }^{+}-\mathrm{N}+11.39 \mathrm{TN}$} & \multirow[t]{3}{*}{41.45} & \multirow[t]{3}{*}{0.001} & \multirow[t]{3}{*}{0.96} & BGB (0.39) \\
\hline & & & & & $\begin{array}{l}\mathrm{NH}_{4}^{+}-\mathrm{N} \\
(0.33)\end{array}$ \\
\hline & & & & & $\mathrm{TN}(0.24)$ \\
\hline \multirow[t]{3}{*}{ G0.34 } & \multirow[t]{3}{*}{$\begin{array}{l}\mathrm{CH}_{4}=55.05-0.11 \text { Rainfall + 0.10SAN + } \\
0.18 \text { Litter }\end{array}$} & \multirow[t]{3}{*}{7.64} & \multirow[t]{3}{*}{0.03} & \multirow[t]{3}{*}{0.82} & $\begin{array}{l}\text { Rainfall } \\
(0.48)\end{array}$ \\
\hline & & & & & SAN (0.14) \\
\hline & & & & & Litter $(0.20)$ \\
\hline \multirow[t]{3}{*}{ G0.46 } & \multirow[t]{3}{*}{$\mathrm{CH}_{4}=60.61-0.14$ Rallfall $+0.10 \mathrm{SAN}+0.04 \mathrm{MBC}$} & \multirow[t]{3}{*}{8.92} & \multirow[t]{3}{*}{0.02} & \multirow[t]{3}{*}{0.84} & $\begin{array}{l}\text { Rainfall } \\
(0.44)\end{array}$ \\
\hline & & & & & SAN (0.28) \\
\hline & & & & & MBC (0.12) \\
\hline \multirow[t]{3}{*}{ G0.69 } & \multirow{3}{*}{$\mathrm{CH}_{4}=23.17+35.30 \mathrm{TN}+0.04 \mathrm{BGB}-1.70 \mathrm{SM}$} & \multirow[t]{3}{*}{51.36} & \multirow[t]{3}{*}{0.00} & \multirow[t]{3}{*}{0.97} & $\mathrm{TN}(0.47)$ \\
\hline & & & & & BGB (0.38) \\
\hline & & & & & SM (0.12) \\
\hline \multirow[t]{3}{*}{ G0.92 } & \multirow[t]{3}{*}{$\mathrm{CH}_{4}=137.88+0.54$ AGB-0.10MBC- $0.45 \mathrm{NH}_{4}{ }^{+}-\mathrm{N}$} & \multirow[t]{3}{*}{4.97} & \multirow[t]{3}{*}{0.06} & \multirow[t]{3}{*}{0.75} & AGB (0.27) \\
\hline & & & & & MBC (0.34) \\
\hline & & & & & $\begin{array}{l}\mathrm{NH}_{4}^{+}-\mathrm{N} \\
(0.14)\end{array}$ \\
\hline
\end{tabular}

Two-way ANOVA analysis indicated that treatment had a significant effect on $\mathrm{CH}_{4}$ uptake rate and vegetation parameters except BGB (Table 2). For soil properties, grazing produced significant effects only on soil moisture and soil $\mathrm{NO}_{3}{ }^{-}-\mathrm{N}$ (Table 2). Interestingly, the interannual variation was significant for all 
variables. The interactive effects from treatment and year were significant on $\mathrm{CH}_{4}$ uptake and vegetation parameters except BGB, but nonsignificant on most soil properties, except soil moisture, total nitrogen, and nitrate.

Table 2

Results of two-way ANOVAs testing the effects of grazing treatment $(T)$ and Year $(Y)$ on the mean and seasonal cumulative soil $\mathrm{CH}_{4}$ uptake, vegetation characteristics, and soil parameters over the study period of $2010-2018 . N *$ and ** represent significance level of at 0.05 and 0.01 , respectively.

\begin{tabular}{|c|c|c|c|c|c|}
\hline Independent Variable & Model & $T$ & $\mathbf{Y}$ & $T * Y$ & $\mathbf{R}^{2}$ \\
\hline Mean $\mathrm{CH}_{4}$ uptake & $4.46^{\star \star}$ & $10.64^{\star \star}$ & $16.93^{\star \star}$ & 1.19 & 0.532 \\
\hline Cumulative $\mathrm{CH}_{4}$ uptake & $4.46^{\star}$ & $10.68^{* *}$ & $16.93^{\star \star}$ & 1.19 & 0.533 \\
\hline Height & $22.05^{\star \star}$ & $194.57 * \star$ & $11.38 * \star$ & $2.62^{\star \star}$ & 0.874 \\
\hline Coverage & $21.90 * \star$ & $89.51^{\star \star}$ & $76.60 * \star$ & 2.51 ** & 0.873 \\
\hline Aboveground biomass (AGB) & 20.24 ** & $150.88^{\star \star}$ & $31.60 * \star$ & $1.64^{\star}$ & 0.864 \\
\hline Belowground biomass (BGB) & $4.19 \star \star$ & 2.21 & $21.00 \star \star$ & 1.07 & 0.512 \\
\hline Litter biomass & $11.13^{\star \star}$ & $60.50 * \star$ & $17.05^{\star \star}$ & $3.77^{\star \star}$ & 0.769 \\
\hline Soil moisture (Ms) & $25.94 * \star$ & 19.56 ** & $150.25^{\star \star}$ & $1.88^{\star \star}$ & 0.891 \\
\hline Soil bulk density (SBD) & $1.93^{\star}$ & 2.00 & $7.24 \star \star$ & 0.86 & 0.234 \\
\hline $\mathrm{pH}$ & $4.93^{\star \star}$ & 1.76 & $27.67 \star \star$ & 0.77 & 0.564 \\
\hline Soil organic carbon (SOC) & $14.46^{\star}$ & 1.29 & $88.61^{\star \star}$ & 1.27 & 0.816 \\
\hline Soil total nitrogen (TN) & $6.21^{\star \star}$ & 1.85 & $32.15^{\star \star}$ & $1.56^{\star}$ & 0.632 \\
\hline Soil available nitrogen (SAN) & $17.47 * \star$ & 1.04 & 110.94 *夫 & 0.83 & 0.844 \\
\hline Soil ammonium nitrogen $\left(\mathrm{NH}_{4}{ }^{+}-\mathrm{N}\right)$ & $60.78^{*}$ & 0.69 & $398.25^{\star \star}$ & 0.80 & 0.952 \\
\hline Soil nitrate nitrogen $\left(\mathrm{NO}_{3}{ }^{-} \mathrm{N}\right)$ & $17.15^{\star \star}$ & $2.30 *$ & $104.04^{\star \star}$ & $1.52^{\star}$ & 0.846 \\
\hline Microbial biomass carbon (MBC) & $4.83^{\star \star}$ & 0.31 & $28.25^{\star \star}$ & 0.71 & 0.558 \\
\hline Microbial biomass nitrogen (MBN) & $2.53^{\star \star}$ & 0.52 & $13.49 * \star$ & 0.59 & 0.335 \\
\hline \multicolumn{6}{|c|}{$\begin{array}{l}\text { Figure } \mathrm{S} 1 \text { Geographic location of the study site and the experimental design in Inner Mongolia. Six } \\
\text { grazing intensities at } 0.00,0.23,0.34,0.46,0.69 \text { and } 0.92 \mathrm{AU} \mathrm{ha}^{-1} \text {. One } \mathrm{AU} \text { is equivalent to a } 500 \mathrm{~kg} \\
\text { adult cow. The stocking rates were achieved by deploying } 0,2,3,4,6 \text { and } 8 \text { young cattle }(\sim 250-300 \\
\mathrm{kg}) \text { per unit. }\end{array}$} \\
\hline
\end{tabular}

\section{Discussion}




\section{Grazing effects on $\mathrm{CH}_{4}$ uptake}

We found two contrasting patterns of $\mathrm{CH}_{4}$ flux in response to increasing stocking rate. In the first two years of grazing, $\mathrm{CH}_{4}$ uptake rate increased with stocking rate (Fig. $2 \mathrm{~A}$ ) with no significant differences detected among the treatments, suggesting that grazing effects on $\mathrm{CH}_{4}$ flux are not immediate. Indeed, the meadow steppe is more resistant to grazing than other steppe types in Inner Mongolia, due to its rich soil (fine textured, well-drained) and vegetation (height, diversity). The dominant plant species (i.e., Leymus chinensis) is more resistant to feeding and trampling than the Stipa spp. that dominate other steppes. Previous studies show that soil moisture and aeration conditions of the L. chinensis steppe are much less prone to grazing trampling, and its regrowth of biomass is also less affected by short-term herbivory, mainly due to the rhizomatous growth form of $L$. chinensis per se, in striking contrast to the bunch growth form of Stipa species (Li et al., 2020). As a result, the activity of $\mathrm{MOB}$ and $\mathrm{CH}_{4}$ uptake were also less affected by grazing in the initial few years in this steppe ecosystem.

An obviously decreasing trend in $\mathrm{CH}_{4}$ uptake with increasing grazing intensity appeared in the following years, with the highest stocking rate showing the greatest negative effects on $\mathrm{CH}_{4}$ uptake (Fig. 2A, 2B). Overall, grazing reduced $\mathrm{CH}_{4}$ uptake of the soil regardless of grazing intensity, which is consistent with most previous studies in typical steppes (Du et al. 1997; Dong et al. 2000; Wang et al. 2000; Wang et al. 2005a, 2005b; Liu et al. 2007; Holst et al. 2008), desert steppes (Tang et al. 2013), and alpine steppes (Wei et al. 2012). Wang et al. (2009) synthesized a number of relevant studies in the typical steppe and found that, on average, the $\mathrm{CH}_{4}$ uptake in grazed grasslands was approximately $68 \%$ of that in un-grazed grasslands. Treating three steppe types in China (i.e., desert, typical and meadow steppes) as a whole, Tang et al. (2013) showed that light grazing did not significantly change $\mathrm{CH}_{4}$ uptake compared with ungrazed steppe, but moderate and heavy grazing reduced $\mathrm{CH}_{4}$ uptake by $6.8 \%$ and $37.9 \%$, respectively. In this study, reductions in $\mathrm{CH}_{4}$ uptake varied between $7.6 \%$ in the light grazing treatment (G0.23) and $25.4 \%$ in the heavy grazing treatment (G0.92), which fall within the range of Tang et al. (2013).

Three mechanisms may be responsible for the changes and differences in $\mathrm{CH}_{4}$ uptake under grazing in our study grassland. First, they may have resulted from changes in vegetation traits due to variable grazing. The $\mathrm{CH}_{4}$ uptake rate significantly positively correlated with the vegetation traits examined in our study (Fig. 5), indicating that the effects of grazing on methane uptake was partially mediated by vegetation. $\mathrm{CH}_{4}$ oxidation in the rhizosphere is the most important process for $\mathrm{CH}_{4}$ cycle, and methanotrophs are developed mainly in the oxidized soil layer and in the aerobic rhizosphere of plants. Here methanotrophs are associated with roots and rhizomes of plants and their activities should correlate with the oxidizing environment of the rhizosphere for MOB (Le Mer and Roger 2001). Changes in litter input and carbohydrate allocation into the soil may play a role in affecting $\mathrm{CH}_{4}$ uptake in this study, although SOM is not the principal energy source for MOB, mainly because SOM may influence the soil food-chain, indirectly affecting the abundance of MOB. By contrast, the effects of vegetation traits on soil moisture and thermal conditions may assume more importance in this regard. 
The second mechanism may be that grazing changes soil $\mathrm{NH}_{4}{ }^{+}-\mathrm{N}$ content and thus affects methane uptake. A significant negative relationship between the $\mathrm{CH}_{4}$ uptake rate and soil $\mathrm{NH}_{4}{ }^{+}-\mathrm{N}$ content was found in this study (Fig. 6). Our long-term data showed that the multi-year mean soil $\mathrm{NH}_{4}{ }^{+}-\mathrm{N}$ content had increased by all grazing treatments, particularly at the highest stocking rate (Zhang et al. 2021). For some years, one- to two-fold increases in soil $\mathrm{NH}_{4}{ }^{+} \mathrm{N}$ content were observed under the highest stocking rate compared to the reference unit (G0.00). Increases in available nitrogen content, soil $\mathrm{NH}_{4}{ }^{+}-\mathrm{N}$ in particular, resulted mainly from livestock excretion of dung and urine. Quite a few studies have showed that methane oxidation potential of upland soils may be reduced by ammonium $\mathrm{N}$-fertilizer application (Mosier et al. 1991; Le Mer and Roger 2001; Täumer et al. 2020). When soil $\mathrm{CH}_{4}$ concentration (<12 ppm) is low, high soil $\mathrm{NH}_{4}{ }^{+}-\mathrm{N}$ concentration can significantly inhibit the methanotroph process (i.e., $\mathrm{CH}_{4}$ oxidation) (Topp and Pattey 1997). It has been reported in an alpine meadow that animal dung was the primary $\mathrm{CH}_{4}$ source, while urine-soaked soil consumed much less $\mathrm{CH}_{4}$ (Lin et al. 2009). In a desert steppe in Inner Mongolia, Jiang et al. (2012) showed that $\mathrm{CH}_{4}$ uptake from urine and dung units decreased by $25.7 \%$ and $33.3 \%$, respectively, compared with a control unit. Wang et al. (2013) also measured $\mathrm{CH}_{4}$ emission from urine and dung patches in a typical steppe. This nitrogen fertilization that led directly or indirectly to an increased soil $\mathrm{NH}_{4}{ }^{+}-\mathrm{N}$ content produced an inhibitory effect on $\mathrm{CH}_{4}$ oxidation through competition of methane monooxygenase towards nitrification and nitrite (Le Mer and Roger 2001). In addition, methanotrophs significantly contributed to nitrification in the rhizosphere, while the contribution of nitrifiers to $\mathrm{CH}_{4}$ oxidation was insignificant (Han et al. 1999).

Thirdly, altered soil moisture by grazing may be another mechanism that regulates $\mathrm{CH}_{4}$ uptake. Our longterm data showed that soil moisture was higher in most cases under various stocking rates of grazing than the no grazing (G0.00) treatment, although no linearly increasing trend of soil moisture with increasing stocking rate was found (Zhang et al. 2021). Stocking-resultant increases in soil moisture were likely related in part to the corresponding decreases in ANPP which consumed less soil water. In addition, we observed that dicotyledonous forbs with deep taproots were significantly more abundant in the nograzing treatment than in all grazing treatments except the intermediate-grazing treatment, which could also be a cause in this regard. Given the significant negative relationship between the $\mathrm{CH}_{4}$ uptake and soil water content (Fig. 6), the decrease in $\mathrm{CH}_{4}$ uptake with stocking rate can be partially explained through the mediating role of soil moisture and increases soil bulk density. Soil submersion allows the development of the methanogenic activity and reduces methanotrophic activity by reducing the size of the oxidized zone. In a typical steppe, $\mathrm{CH}_{4}$ uptake was primarily determined by soil temperature and soil moisture of the topsoil $\left(7 \mathrm{~cm}\right.$ ) (Wang et al. 2005a). Negative correlation between $\mathrm{CH}_{4}$ uptake and soil moisture was reported in an alpine steppe (Wei et al. 2012) and temperate steppes (Tang et al. 2013). At Swiss grassland sites, the soil methanotrophic activity is related to its water content. With the increase of water content, it gradually decreases and is close to the field capacity (Imer et al. 2013). Negative correlations between $\mathrm{CH}_{4}$ consumption and soil moisture were also reported in Canadian forests and in a Massachusetts forest (Le Mer and Roger 2001). Upland soils, when temporarily submerged, may become 
$\mathrm{CH}_{4}$ sources. This was also observed in a Canadian grassland with well drained soils (Wang and Bettany 1995).

A positive correlation is often observed between the methanogenic potential and the SOM content in rice field soils, and almost all in situ studies have shown that organic matter incorporation markedly increased $\mathrm{CH}_{4}$ emission. However, a positive relationship between $\mathrm{CH}_{4}$ uptake and soil $\mathrm{SOC}$ content was detected in this study (Fig. 6), which may reflect the fact that grassland soils per se have rather low methanogenic potentials. This can be further corroborated by the fact that $\mathrm{CH}_{4}$ production is often positively correlated with SOM content in soils exhibiting a high methanogenic activity (Le Mer and Roger 2001).

\section{Complexity of grazing regulation on $\mathrm{CH}_{4}$ uptake}

Our multivariate linear regression analysis indicated that livestock grazing had substantially changed the interannual variation of both $\mathrm{CH}_{4}$ uptake and its biophysical regulators in this steppe ecosystem (Fig. 3A, $3 \mathrm{~B}$; Table 1). The increasing trends of $\mathrm{CH}_{4}$ uptake with year in the no-grazing (G0.00) and light grazing treatments $(\mathrm{G} 0.23)$ may reflect a progressive successional process of the ecosystem under these treatments. In fact, this steppe had been under heavy grazing for ages prior to our experiment. As such, the vegetation and soil nutrient conditions should have improved compared with the start of the experiment under no grazing or light grazing conditions. Nevertheless, the control stand was far from the pristine stand in terms of vegetation and soil regimes. This may partially explain the non-significant differences in soil conditions, making it difficult to explain variation in $\mathrm{CH}_{4}$ uptake along the grazing gradient. The positive correlations between $\mathrm{CH}_{4}$ uptake and vegetation characteristics, $\mathrm{SOC}$ and total nitrogen contents (Figs. 5, 6) provide empirical evidences of an ecosystem recovery process (i.e., reduced grazing impacts). The positive relationships between $\mathrm{CH}_{4}$ uptake rate and vegetation coverage and BGB (Table 1) also support this assumption. The negative relationships between $\mathrm{CH}_{4}$ uptake and the soil $\mathrm{NH}_{4}{ }^{+}-\mathrm{N}$ content (Tables 1,2$)$, however, suggest that other factors may be responsible for the interannual variations of $\mathrm{CH}_{4}$ uptake under these light grazing treatments.

Under the light (G0.34) and intermediate (G0.46) grazing treatments (Fig. 3A), both increase and decrease in $\mathrm{CH}_{4}$ uptake with year may reflect a standstill status over the successional process of the ecosystem since the start of the fencing. Here no significant changes in the vegetation characteristics and soil nutrient conditions had occurred. Climatic factors, especially rainfall, became the predominant driver for interannual dynamics of $\mathrm{CH}_{4}$ uptake (Table 1). The negative relationships between rainfall and $\mathrm{CH}_{4}$ uptake under these treatments may reflect the negative impacts of the soil $\mathrm{NH}_{4}{ }^{+}-\mathrm{N}$ content on $\mathrm{CH}_{4}$ uptake, whereas the positive relationships between $\mathrm{CH}_{4}$ uptake and soil available nitrogen (Table 1) are likely due to the impacts of soil $\mathrm{NO}_{3}{ }^{+} \mathrm{N}$ on the $\mathrm{CH}_{4}$ dynamics, coupled with the methanotrophic and the nitrification process (Han et al. 1999; Le Mer and Roger 2001) where the excretion of dung and urine played an important role. 
With the heavy (G0.69) and over-grazing (G0.92) treatments, the decreasing trends of $\mathrm{CH}_{4}$ uptake with year may reflect a retrogressive successional process by grazing. Here vegetation characteristics and soil conditions were significantly affected over the years ( $\mathrm{Li}$ et al. 2021) and, consequently regulate $\mathrm{CH}_{4}$ dynamics (Table 1). The positive correlations between $\mathrm{CH}_{4}$ uptake and vegetation, $\mathrm{SOC}$ and total nitrogen contents (Figs. 5, 6) demonstrated their coupled influences on $\mathrm{CH}_{4}$ uptake (Table 1). The negative relationship between $\mathrm{CH}_{4}$ uptake and the soil $\mathrm{NH}_{4}{ }^{+}-\mathrm{N}$ content (Table 1) further indicate that $\mathrm{NH}_{4}{ }^{+}-\mathrm{N}$ content continued its role in regulating the interannual dynamics of $\mathrm{CH}_{4}$ uptake under the over-grazing treatment. However, the relative importance of soil $\mathrm{NH}_{4}{ }^{+}-\mathrm{N}$ was substantially underestimated in our multivariate linear regression analysis (Tables 1,2 ). As previously discussed, dung was a significant $\mathrm{CH}_{4}$ source, while urine patches restricted $\mathrm{CH}_{4}$ consumption (Lin et al. 2009; Wang et al. 2013). The dung and urine patches under the over-grazing treatment in this study had covered about one-tenth of the entire steppe ground during each stocking season, which should have much more substantial impacts on the soil nitrogen budget. However, the nitrogen input via this way is difficult to be captured by measuring the soil contents of available components $\left(\mathrm{NH}_{4}{ }^{+}-\mathrm{N}_{1} \mathrm{NO}_{3}{ }^{-} \mathrm{N}\right)$ due to their rapid volatile nature and their being prone to plant absorption. The negative relationship between the $\mathrm{CH}_{4}$ uptake rate and soil water content detected in the heavy grazing treatment (Table 1 ) is mechanistically clear, while we did find that the interannual $\mathrm{CV}$ of soil moisture under this treatment was the second largest among all the treatments.

We found some inconsistent and even contradictory results with previous reports on the impacts of livestock grazing on grassland soil $\mathrm{CH}_{4}$ uptake, partially due to the inconsistency in the number of study years and grazing intensity. Most previous studies were conducted in a single season or over 1-3 years. These studies did not have a broad range of stocking rates, either (i.e., limited to $1-3$ grazing intensities). Clearly, long-term treatments with multiple stocking rates should be studied in other worldwide grasslands.

Our hypothesis that livestock grazing imposes impacts on methane dynamics in grassland soils through trampling, selective feeding, and excretion of dung and urine is generally accepted. These impacts are induced through alterations of soil moisture, aboveground biomass, and soil total nitrogen and $\mathrm{NH}_{4}{ }^{+}-\mathrm{N}$ contents. Our findings are partially in agreement with some previous studies (Du et al. 1997; Wang et al. 2009; Wei et al. 2012). However, we have not teased apart the contributions of three grazing actions in the present study: trampling, vegetation-feeding, and excretion of dung and urine. Continued efforts are needed to see if the findings may shift over even longer time scales (e.g., decades), along with added efforts in partitioning the three specific grazing actions in the future.

\section{Conclusion}

We showed that the meadow steppe ecosystem acted as a significant $\mathrm{CH}_{4}$ sink, irrespective of stocking rate and year. With increasing grazing intensity, $\mathrm{CH}_{4}$ uptake rate decreased in a sigmoid curve-shaped manner, with the threshold grazing intensity (inflection point) being at the light grazing (G0.34). The 
interannual variation of $\mathrm{CH}_{4}$ uptake depended on grazing intensity. An increasing $\mathrm{CH}_{4}$ uptake was found under the no-grazing (G0.00) and light grazing (G0.23) treatment, while a stable uptake was apparent under G0.34 treatment and a decreasing trend was seen for all other treatments. Major factors affecting $\mathrm{CH}_{4}$ uptake among the treatments include vegetation characteristics, soil moisture and soil nitrogen regime, with soil $\mathrm{NH}_{4}{ }^{+}-\mathrm{N}$ content assuming the most importance role. Interannual variations of $\mathrm{CH}_{4}$ uptake were dominated by rainfall, belowground biomass (BGB), and soil nitrogen regime. Continued efforts are needed to see if our findings hold at longer time scales, as well as in other steppe ecosystems. We recognize that multi-year studies across a wider range of stocking rates are extremely necessary to test the effects of grazing on $\mathrm{CH}_{4}$ uptake in global grassland ecosystems.

\section{Declarations}

The authors declare that they have no known competing financial interests or personal relationships that could have appeared to influence the work reported in this paper.

\section{Acknowledgments}

This work was supported by the National Key Research and Development Program of China (2017YFE0104500, 2016YFC0500601), the National Natural Science Foundation of China (31971769), the Fundamental Research Funds for Central Non-profit Scientific Institution (Y2020YJ19, 1610132021016), and the LCLUC program of NASA (80NSSC20K0410) to J. Chen, Special Funding for Modern Agricultural Technology Systems from the Chinese Ministry of Agriculture (CARS-34), Hulunbuir Science and Technology Project (YYYFHZ201903), and Construction of Agricultural Science and Technology Innovation Alliance - Agriculture Basic Long-Term Scientific and Technological Work (NAES037SQ18). We thank Kristine Blakeslee of MSU for editing the English of this manuscript. Two anonymous reviewers provided constructive suggestions for improving the quality of this paper.

\section{References}

1. Bao S (2000) Soil Agrochemical Analysis. China Agriculture Press, Beijing

2. Bagchi S, Ritchie ME (2010) Introduced grazers can restrict potential soil carbon sequestration through impacts on plant community composition. Ecol Lett 13(8). https://doi.org/ 10.1111/j.1461 -0248.2010.01486.x

3. Billings SA, Richter DD, Yarie J (2000) Sensitivity of soil methane fluxes to reduced precipitation in boreal forest soils. Soil Biol Biochem 32(10):1431-1441. https://doi.org/10.1016/S00380717(00)00061-4

4. Bodelier PLE, Gilissen MJB, Franke MM, Hordijk K (2012) Structural and functional response of methane-consuming microbial communities to different flooding regimes in riparian soils. Ecol Evol 2(1):106-127. https://doi.org/10.1002/ece3.34 
5. Castaldi S, Fierro A (2005) Soil-atmosphere methane exchange in undisturbed and burned Mediterranean shrubland of southern Italy. Ecosystems 8(2):182-190. https://doi.org/10.2307/25053815

6. Chen WW, Wolf B, Yao ZS, Brüggemann N, Butterbach-Bahl K, Liu CY, Han SH, Han XG, Zheng XH (2010) Annual methane uptake of typical semi-arid steppe in Inner Mongolia. J Geophys Res Atmos 115:D15108. https://doi.org/10.1029/2009JD013783

7. Chen W, Wolf B, Brüggemann N, Butterbach-Bahl K, Zheng X (2011a) Annual emissions of greenhouse gases from sheepfolds in Inner Mongolia. Plant Soil 340:291-301. https://doi.org/10.1007/s11104-010-0367-5

8. Chen W, Wolf B, Zheng X, Yao Z, Butterbach-Bahl K, Brüggemann N, Liu C, Han S, Han X (2011b) Annual methane uptake by temperate semiarid steppes as regulated by stocking rates, aboveground plant biomass and topsoil air permeability. Glob Change Biol 17:2803-2816. https://doi.org/10.1111/j.1365-2486.2011.02444.x

9. Chen WW, Zheng XH, Chen Q, Wolf B, Butterbach-Bahl K, Brüggemann N, Lin S (2013) Effects of increasing precipitation and nitrogen deposition on $\mathrm{CH}_{4}$ and $\mathrm{N}_{2} \mathrm{O}$ fluxes and ecosystem respiration in a degraded steppe in Inner Mongolia, China. Geoderma 192:335-340.

https://doi.org/10.1016/j.geoderma.2012.08.018

10. Cicerone RJ, Oremland RS (1988) Biogeochemical aspects of atmospheric methane. Global Biogeochem Cy 2(4):299-327. https://doi.org/10.1029/GB002i004p00299

11. Cui XY, Wang YF, Niu HS, Wu J, Wang SP, Schnug E, Rogasik J, Fleckenstein J, Tang YH (2005) Effect of long-term grazing on soil organic carbon content in semiarid steppes in Inner Mongolia. Ecol Res 20(5):519-527. https://doi.org/10.1007/s11284-005-0063-8

12. Dijkstra FA, Morgan JA, Von Fischer JC, Follett RF (2011) Elevated $\mathrm{CO}_{2}$ and warming effects on $\mathrm{CH}_{4}$ uptake in a semiarid grassland below optimum soil moisture. J Geophys Res Biogeo 116:79-89. https://doi.org/10.1029/2010JG001288

13. Del Grosso SJ, PartonWJ, Mosier AR, Ojima DS, Potter CS, Borken W, Brumme R, Butterbach-Bahl K, Crill PM, Dobbie K, Smith KA (2000) General $\mathrm{CH}_{4}$ oxidation model and comparisons of $\mathrm{CH}_{4}$ oxidation in natural and managed systems. Global Biogeochem Cy 14:999-1019. https://doi.org/10.1029/1999GB001226

14. Dong YS, Zhang S, Qi YC, Chen ZZ, Geng YB (2000) Fluxes of $\mathrm{CO}_{2}, \mathrm{~N}_{2} \mathrm{O}$ and $\mathrm{CH}_{4}$ from typical temperate grassland in Inner Mongolia and its daily variation. Chinese Sci Bull 45(17):1590-1594. https://doi.org/10.1007/bf02886219

15. Du R, Chen GX, Lu DR, Wang GC (1997) The primary research on in situ measurements of $\mathrm{N}_{2} \mathrm{O}$ and $\mathrm{CH}_{4}$ fluxes from the Inner Mongolia grassland ecosystem (in Chinese). Journal of Climate Environmental Research 2:264-272

16. Dunfield PF (2007) The soil methane sink. In: Reay DS, Hewitt CN, Smith KA, Grace J (eds) Greenhouse gas sinks. CABI, Wallingford, pp 152-170. https://doi.org/10.1079/9781845931896.0152 
17. Fan Y, Chen J, Shirkey G, John R, Wu SR, Park H, Shao CL (2016) Applications of structural equation modeling (SEM) in ecological studies: an updated review. Ecol Proc 5(1):19. https://doi.org/10.1186/s13717-016-0063-3

18. Fayez R, Esmael A (2006) Soil microbial activity and litter turnover in native grazed and ungrazed rangelands in semiarid ecosystem. Biol Fert Soils 43:76-82. https://doi.org/10.1007/s00374-0050066-1

19. Frank AB, Liebig MA, Hanson JD (2002) Soil carbon dioxide fluxes in northern semiarid grasslands. Soil Biol Biochem 34:1235-1241. https://doi.org/10.1016/S0038-0717(02)00062-7

20. Frank DA, Gehring CA, Machut L, Phillips M (2003) Soil community composition and the regulation of grazed temperate grassland. Oecologia 442:603-609. https://doi.org/10.1007/s00442-003-13852

21. Gao YZ, Giese M, Lin S, Taube F, Brueck H (2008) Belowground net primary productivity and biomass allocation of a grassland in Inner Mongolia as affected by grazing intensity. Plant Soil 307:41-50. https://doi.org/10.1007/s11104-008-9579-3

22. Geng YB, Luo GQ, Yuan GF (2010) $\mathrm{CH}_{4}$ uptake flux of Leymus chinensis steppe during rapid growth season in Inner Mongolia, China. Sci China Earth Sci 53:977-983. https://doi.org/10.1007/s11430010-3082-4

23. Gulledge J, Schimel JP (1998) Moisture control over atmospheric $\mathrm{CH}_{4}$ consumption and $\mathrm{CO}_{2}$ production in diverse Alaskan soils. Soil Biol Biochem 30:1127-1132. https://doi.org/10.1016/S0038-0717(97)00209-5

24. Gutman G, Chen JQ, Henebry G, Kappas (Eds.)M (2020) Landscape dynamics of drylands across greater central Asia: people, societies and ecosystems. Springer. https://doi.org/10.1007/978-3-03030742-4

25. Han XG, Li LH, Huang JH (1999) An Introduction to Biogeochemistry. Chinese Higher Education Press, Beijing, pp 181-184

26. Holst J, Liu C, Yao Z, Brüggemann N, Zheng X, Giese M, Butterbach-Bahl K (2008) Fluxes of nitrous oxide, methane and carbon dioxide during freezing-thawing cycles in an Inner Mongolian steppe. Plant Soil 308(1-2):105-117. https://doi.org/10.1016/10.1007/s11104-008-9610-8

27. Hu FL, Yan Y, Lu XQ, Wu J, Ding H, Liu ZM (2016) Carbon distribution pattern of grassland biomass in Inner Mongolia. J of Grassland Industry 25(4)

28. Hutchinson GL, Mosier AR (1981) Improved soil cover method for field measurements of nitrous oxide fluxes. Soil Sci Soc Am J 45:311-316. https://doi.org/10.2136/sssaj1981.03615995004500020017x

29. Imer D, Merbold L, Eugster W, Buchmann N (2013) Temporal and spatial variations of soil $\mathrm{CO}_{2}, \mathrm{CH}_{4}$ and $\mathrm{N}_{2} \mathrm{O}$ fluxes at three differently managed grasslands. Bio Geosciences 10(9):5931-5945. https://doi.org/10.5194/bg-10-5931-2013 
30. IPCC [Intergovernmental Panel on Climate Change] (2013) Climate change 2013: the physical science basis. Pages 659-740. In: Stocker TF, Qin D, Plattner G-K, Tignor M, Allen SK, Boschung J, Nauels A, Xia Y, Bex V, Midgley PM (eds) Contribution of Working Group I to the Fifth Assessment Report of the Intergovernmental Panel on Climate Change. Cambridge University Press, Cambridge

31. Jiang YY, Tang S, Wanga C, Zhou P, Tenuta M (2012) Contribution of urine and dung patches from grazing sheep to methane and carbon dioxide fluxes in an Inner Mongolian desert grassland. Asian Austral J Anim 25(2):207-212. https://doi.org/10.5713/ajas.2011.11261

32. Jones SK, Rees RM, Skiba UM, Ball BC (2005) Greenhouse gas emissions from a managed grassland. Glob Planet Change 47(2-4):201-211. https://doi.org/10.1016/j.gloplacha.2004.10.011

33. John R, Chen JQ, Giannico V, Park H, Xiao JF, Shirkey G, Ouyang Z, Shao CL, Lafortezza R, Qi JG (2018) Grassland canopy cover and aboveground biomass in Mongolia and Inner Mongolia: spatiotemporal estimates and controlling factors. Remote Sens Environ 213:34-48. https://doi.org/10.1016/j.rse.2018.05.002

34. Keller M, Goreau TJ, Wofsy SC, Kaplan WA, McElroy MB (1983) Production of nitrous oxide and consumption of methane by forest soils. Geophys Res Lett 10:1156-1159. https://doi.org/10.1029/GL010i012p01156

35. Knief C, Lipski A, Dunfield PF (2003) Diversity and activity of methanotrophic bacteria in different upland soils. Appl Environ Microbiol 69:6703-6714. https://doi.org/10.1128/aem.69.11.67036714.2003

36. Knox SH, Jackson RB, Poulter B, McNicol G, Fluet-Chouinard E, Zhang Z, Hugelius G, Bousquet P, Canadell JG, Saunois M, Papale D, Chu H, Keenan TF, Baldocchi D, Torn MS, Mammarella I, Trotta C, Aurela M, Bohrer G, Campbell DI, Cescatti A, Chamberlain S, Chen J, Chen W, Dengel S, Desai AR, Euskirchen E, Friborg T, Gasbarra D, Goded I, Goeckede M, Heimann M, Helbig M, Hirano T, Hollinger DY, Iwata H, Kang M, Klatt J, Krauss KW, Kutzbach L, Lohila A, Mitra B, Morin TH, Nilsson MB, Niu S, Noormets A, Oechel WC, Peichl M, Peltola O, Reba ML, Richardson AD, Runkle BRK, Ryu Y, Sachs T, Schäfer KVR, Schmid HP, Shurpali N, Sonnentag O, Tang ACl, Ueyama M, Vargas R, Vesala T, Ward EJ, Windham-Myers L, Wohlfahrt G, Zona D (2019) Fluxnet- $\mathrm{CH}_{4}$ synthesis activity: objectives, observations, and future directions. B Am Meteorol Soc 100(12). https://doi.org/10.1175/BAMS-D18-0268.1

37. Kolb S, Knief C, Dunfield PF, Conrad R (2005) Abundance and activity of uncultured methanotrophic bacteria involved in the consumption of atmospheric methane in two forest soils. Environ Microbiol 7:1150-1161. https://doi.org/10.1111/j.1462-2920.2005.00791.x

38. Koschorreck M, Conrad R (1993) Oxidation of atmospheric methane in soil: measurements in the field, in soil cores and in soil samples. Global Biogeochem Cy 7(1):109-121. https://doi.org/10.1029/92GB02814

39. Kravchenko I, Boeckx P, Galchenko V, Van Cleemput O (2002) Short- and medium-term effects of $\mathrm{NH}_{4}{ }^{+}$on $\mathrm{CH}_{4}$ and $\mathrm{N}_{2} \mathrm{O}$ fluxes in arable soils with a different texture. Soil Biol Biochem 34:669-678. https://doi.org/10.1016/S0038-0717(01)00232-2 
40. Le Mer JL, Roger $P$ (2001) Production, oxidation, emission and consumption of methane by soils: a review. Eur J Soil Biol 37:25-50. https://doi.org/10.1016/S1164-5563(01)01067-6

41. Li LH, Chen JQ, Han XG, Zhang WH, Shao CL (2020) Grassland Ecosystems of China. Springer, Singapore. https://doi.org/10.1007/978-981-15-3421-8

42. Li LH (2021) Chinese Vegetation and Environmental Change. China Agricultural University Press, Beijing

43. Lin X, Wang S, Ma X, Xu G, Luo C, Li Y, Jiang G, Xie Z (2009) Fluxes of $\mathrm{CO}_{2}, \mathrm{CH}_{4}$, and $\mathrm{N}_{2} \mathrm{O}$ in an alpine meadow affected by yak excreta on the Qinghai-Tibetan plateau during summer grazing periods. Soil Biol Biochem 41(4):718-725. https://doi.org/10.1016/j.soilbio.2009.01.007

44. Liu C, Holst J, Brüggemann N, Butterbach-Bahl K, Yao Z, Yue J, Han S, Han X, Krümmelbein J, Horn R, Zheng X (2007) Winter-grazing reduces methane uptake by soils of a typical semi-arid steppe in Inner Mongolia. China Atmos Environ 41:5948-5958. https://doi.org/10.1016/j.atmosenv.2007.03.017

45. Liu C, Holst J, Brüggemann N, Butterbach-Bahl K, Yao Z, Han S, Han X, Zheng X (2008) Effects of irrigation on nitrous oxide, methane and carbon dioxide fluxes in an Inner Mongolian steppe. Adv Atmos Sci 25(005):748-756. https://doi.org/10.1007/s00376-008-0748-3

46. Liu CY, Holst J, Yao ZH, Brüggemann N, Butterbach-Bahl K, Han SH, Han XG, Tas B, Susenbeth A, Zheng XH (2009) Growing season methane budget of an Inner Mongolian steppe. Atmos Environ 43(19):3086-3095. https://doi.org/10.1016/j.atmosenv.2009.03.014

47. Mancinelli RL (1995) The regulation of methane oxidation in soil. Ann Rev Microbiol 49(1):581-605. https://doi.org/10.1146/annurev.micro.49.1.581

48. Mosier AR, Bronson K, Schimel D, Valentine D, Parton W (1991) Methane and nitrous oxide fluxes in native, fertilized and cultivated grasslands. Nature 350:330-332. https://doi.org/10.1038/350330a0

49. Mosier AR, Delgado JA (1997) Methane and nitrous oxide fluxes in grasslands in western Puerto Rico. Chemosphere 35(9):2059-2082. https://doi.org/10.1016/S0045-6535(97)00231-2

50. Mosier AR, Morgan JA, King JY, LeCain D, Milchunas DG (2002) Soil-atmosphere exchange of $\mathrm{CH}_{4}$, $\mathrm{CO}_{2}, \mathrm{NO}_{x}$ and $\mathrm{N}_{2} \mathrm{O}$ in the Colorado shortgrass steppe under elevated $\mathrm{CO}_{2}$. Plant Soil 240(2):201-211. https://doi.org/10.5194/acpd-3-2691-2003

51. Potter CS, Davidson EA, Verchot LV (1996) Estimation of global biogeochemical controls and seasonality in soil methane consumption. Chemosphere 32:2219-2246. https://doi.org/10.1016/S1352-2310(97)80971-5

52. Qi JG, Xin XP, John R, Groisman PP, Chen JQ (2017) Understanding livestock production and sustainability of grassland ecosystems in the Asian Dryland Belt. Ecol Proc 6(1):22. https://doi.org/10.1186/s13717-017-0087-3

53. Saggar S, Hedley CB, Giltrap DL, Lambie SM (2007) Measured and modelled estimates of nitrous oxide emission and methane consumption from a sheep-grazed pasture. Agric Ecosyst Environ 122:357-365. https://doi.org/10.1016/j.agee.2007.02.006 
54. Schönbach P, Wolf B, Dickhfer U, Wiesmeier M, Chen WW, Wan HW, Gierus M, Butterbach-Bahl K, KgelKnabner I, Susenbeth A (2012) Grazing effects on the greenhouse gas balance of a temperate steppe ecosystem. Nutr Cycl Agroecosyst 93(3):357-371. https://doi.org/10.1007/s10705-012-9521-1

55. Steenwerth KL, Jackson LE, Calderon FJ, Scow KM, Rolston DE (2005) Response of microbial community composition and activity in agricultural and grassland soils after a simulated rainfall. Soil Biol Biochem 37:2249-2262. https://doi.org/10.1016/j.soilbio.2005.02.038

56. Tang SM, Wang CJ, Wilkes A, Zhou P, Jiang Y, Han G, Zhao M, Huang D, Schönbach P (2013) Contribution of grazing to soil atmosphere $\mathrm{CH}_{4}$ exchange during the growing season in a continental steppe. Atmos Environ 67:170-176. https://doi.org/10.1016/j.atmosenv.2012.10.037

57. Topp E, Pattey E (1997) Soils as sources and sinks for atmospheric methane. Can J Soil Sci 77(2):167-178. https://doi.org/10.4141/S96-107

58. Tumer J, Kolb S, Boeddinghaus RS, Wang H, Schning I, Schrumpf M, Urich T, Marhan S (2020) Divergent drivers of the microbial methane sink in temperate forest and grassland soils. Glob Change Biol. https://doi.org/10.1111/gcb.15430

59. Tveit AT, Hestnes AG, Robinson SL et al (2019) Widespread soil bacterium that oxidizes atmospheric methane. PNAS. https://doi.org/10.1073/pnas.1817812116

60. Wang FL, Bettany JR (1995) Short Communication:Methane emission from a usually well-drained prairie soil after snowmelt and precipitation. Can J Soil Sci 75(2):239-241. https://doi.org/10.4141/cjss95-033

61. Wang XY, Ding H, Zhang YJ, Chen WQ, Wang CJ, Yang XM, Luo W (2013) Dynamic changes of $\mathrm{CH}_{4}$ and $\mathrm{CO}_{2}$ emission from grazing sheep urine and dung patches in typical steppe. Atmos Environ 79(nov.):576-581. https://doi.org/10.1016/j.atmosenv.2013.07.003

62. Wang YF, Ji BM, Chen ZZ, Dennis O (2000) Preliminary results of a study on $\mathrm{CH}_{4}$ flux in Xilin River basin steppe under different grazing intensities. Acta Phytoecologia Sinica 24(6):693-696. https://doi.org/10.1088/0256-307X/17/9/008

63. Wang YS, Xue M, Zheng XH, Ji BM, Du R, Wang YF (2005a) Effects of environmental factors on $\mathrm{N}_{2} \mathrm{O}$ emission from and $\mathrm{CH}_{4}$ uptake by the typical grasslands in the Inner Mongolia. Chemosphere 58:205-215. https://doi.org/10.1016/j.chemosphere.2004.04.043

64. Wang ZP, Han XG, Li LH, Chen QS, Duan Y, Cheng WX (2005b) Methane emission from small wetlands and implications for semiarid region budgets. J Geophys Res 110:D13304. https://doi.org/10.1029/2004JD005548

65. Wang ZP, Song Y, Gulledge J, Yu Q, Liu HS, Han XG (2009) China's grazed temperate grasslands are a net source of atmospheric methane. Atmos Environ 43(13):2148-2153. https://doi.org/10.1016/j.atmosenv.2009.01.021

66. Wei D, Xu R, Wang Y, Wang Y, Liu Y, Yao T (2012) Responses of $\mathrm{CO}_{2}, \mathrm{CH}_{4}$ and $\mathrm{N}_{2} \mathrm{O}$ fluxes to livestock enclosure in an alpine steppe on the tibetan plateau, China. Plant Soil 359(1-2):45-55. https://doi.org/10.1007/s11104-011-1105-3 
67. White RP, Murray S, Rohweder M (2000) Pilot Analysis of Global Ecosystem: Grassland Ecosystems. World Resource Institute, Washington, DC. https://doi.org/10.1038/nclimate1223

68. Wolf B, Zheng X, Brüggemann N, Chen W, Dannenmann M, Han X, Sutton MA, Wu H, Yao Z, Butterbach-Bahl K (2010) Grazing-induced reduction of natural nitrous oxide release from continental steppe. Nature 464:881-884. https://doi.org/10.1038/nature08931

69. Yan R, Tang H, Xin X, Chen B, Murray PJ, Yan Y, Wang X, Yang G (2016) Grazing intensity and driving factors affect soil nitrous oxide fluxes during the growing seasons in the Hulunber meadow steppe of China. Environ Res Lett 11:054004. https://doi.org/10.1088/1748-9326/11/5/054004

70. Zhang Y, Zhao JL, Xin XP, Wang M, Pan FJ, Yan RR, Li LH (2021) Effects of stocking rate on the interannual patterns of ecosystem biomass and soil nitrogen mineralization in a meadow steppe of northeastern China. Plant Soil 1-23. https://doi.org/10.1007/s11104-021-04901-4

71. Zhou XQ, Wang YF, Huang XZ, Tian JQ, Hao YB (2008) Effect of grazing intensities on the activity and community structure of methane-oxidizing bacteria of grassland soil in Inner Mongolia. Nutr Cycl Agroecosyst 80(2):145-152. https://doi.org/10.1007/s10705-007-9127-1

\section{Figures}

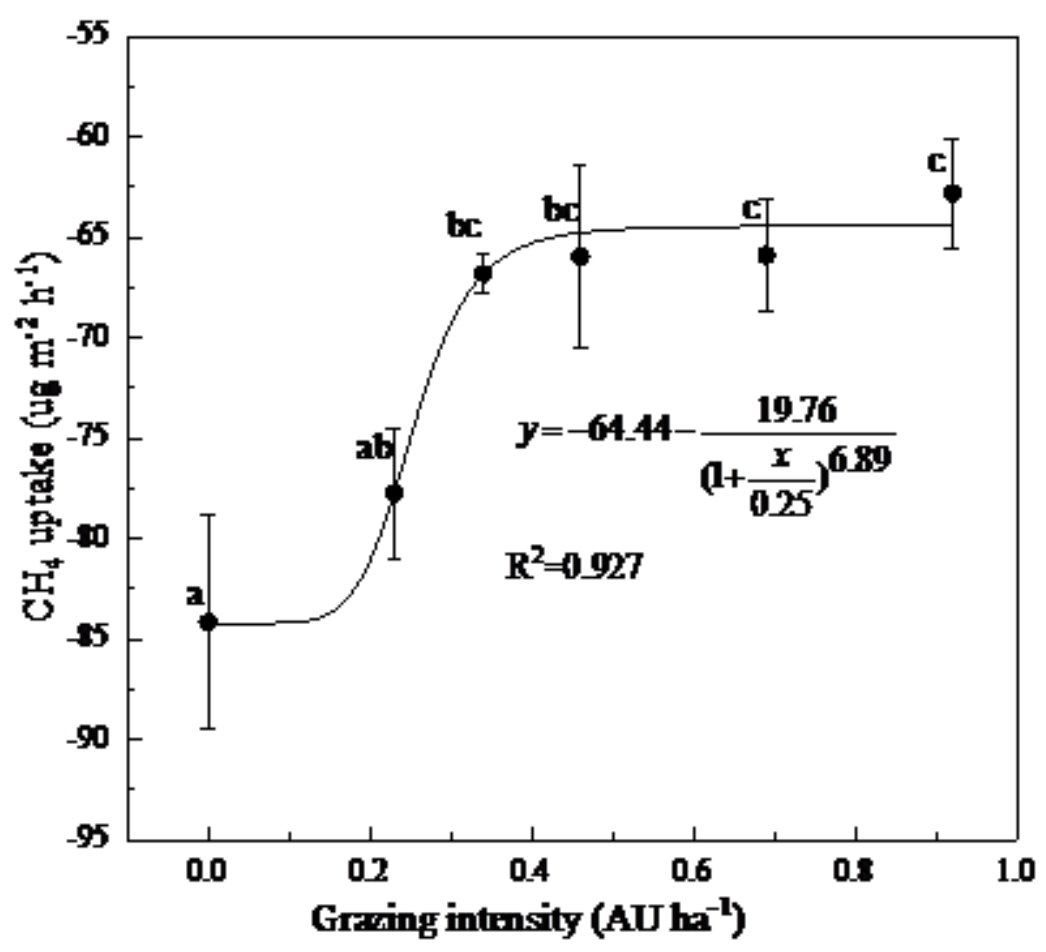

Figure 1

Change in annual mean $\mathrm{CH} 4$ uptake (i.e., negative values) under different grazing treatments from 2010 through 2018. Bars represent the standard errors of the seasonal means. A simple logistic model is used to predict $\mathrm{CH} 4$ uptake with grazing intensity. The letters indicate significant differences between the treatments in one-way ANOVA at $\mathrm{P}<0.05$. 

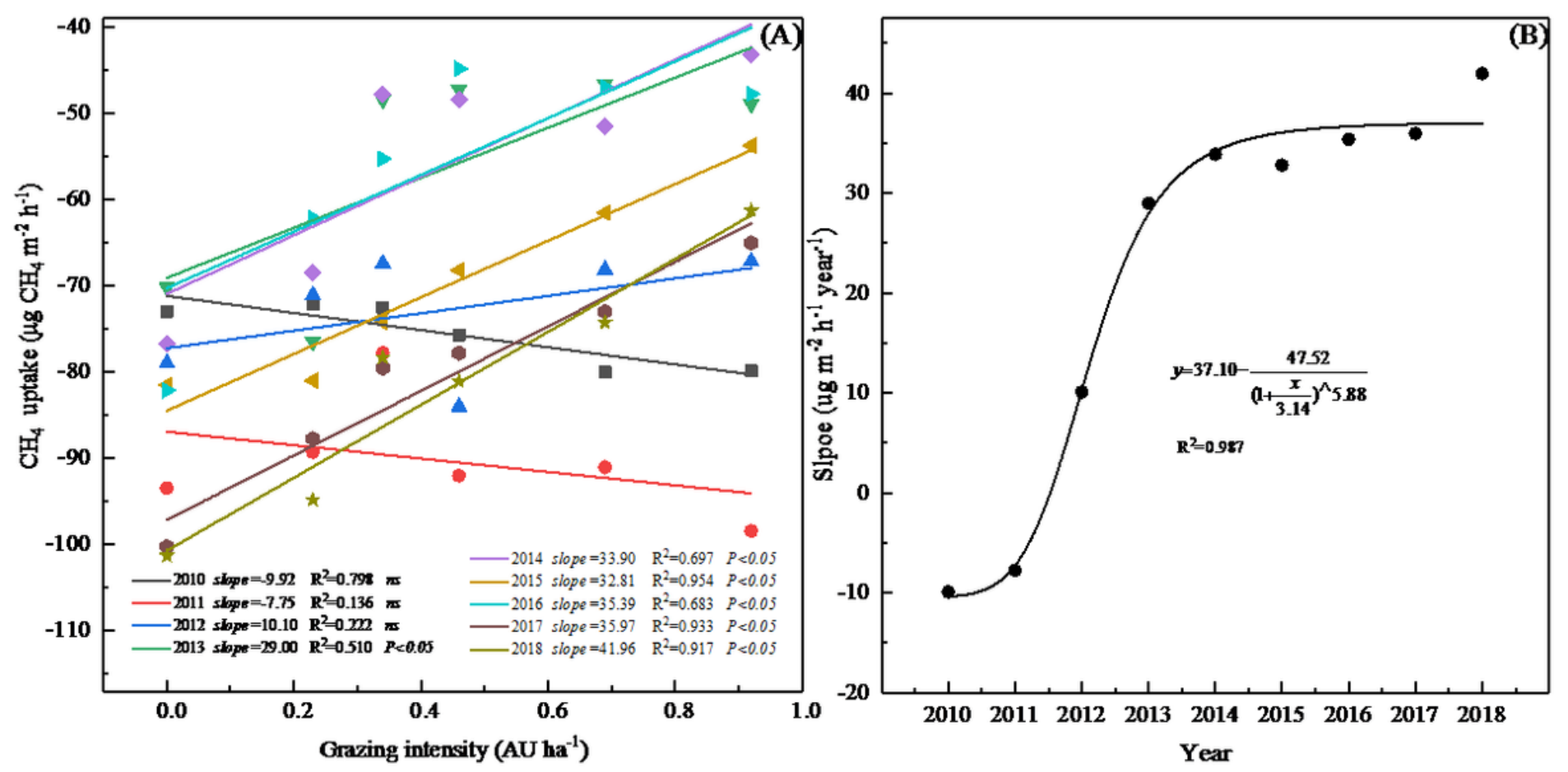

Figure 2

(A) Changes in mean ( \pm se) $\mathrm{CH} 4$ uptake rate with grazing treatments by year from 2010 through 2018 . Simple linear regression is presented to demonstrate the direction (i.e., positive vs negative) and the magnitudes (i.e., regression slopes) for each year. Significance level is labeled as: NS $(P>0.05)$ and $(P<0.05)$. (B) Change in slope of simple linear regression models with year. A logistic model is applied to empirically fit the change.
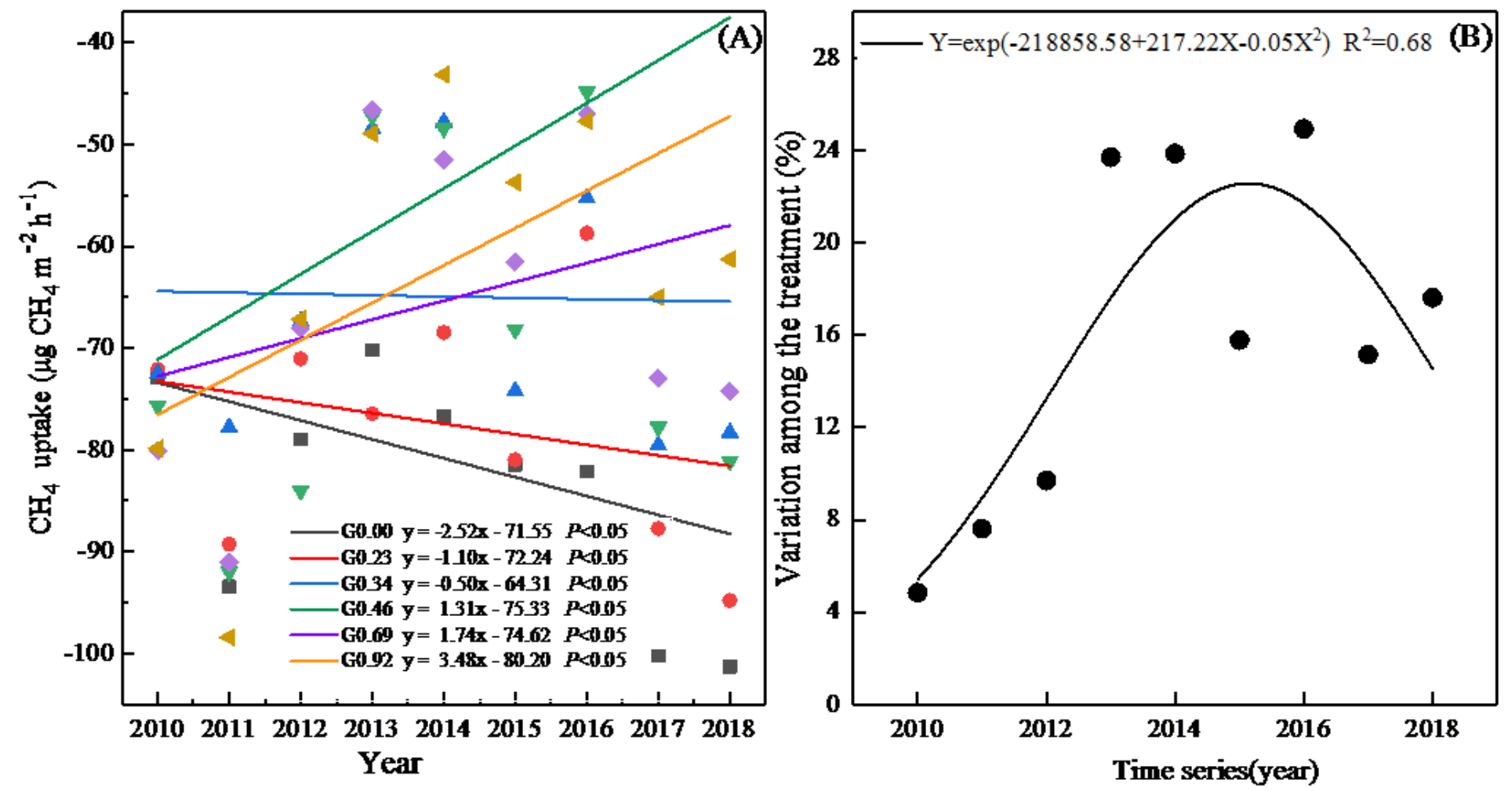
Figure 3

(A) Change in $\mathrm{CH} 4$ uptake rate with year by treatment, showing a continued increase in $\mathrm{CH} 4$ uptake at $\mathrm{G} 0.00$ and $\mathrm{G} 0.23$, insignificant change at G0.34, and weakened trending at G0.46-G0.92. (B) Change in variation $(\mathrm{CVs})$ of $\mathrm{CH} 4$ uptake among the grazing treatments with year.

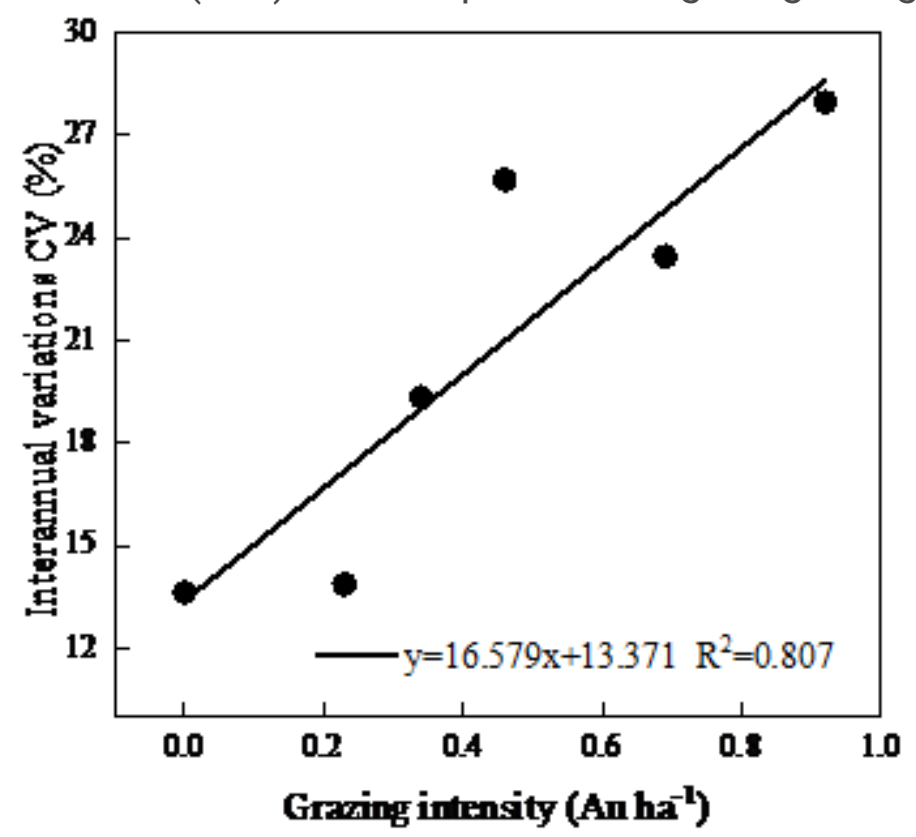

Figure 4

Linear increase of interannual variations (CVs) in $\mathrm{CH} 4$ uptake strength with grazing intensity. $\mathrm{CV}$ represents the confidence interval of $\mathrm{CH} 4$ uptake over the 9-year study period. 

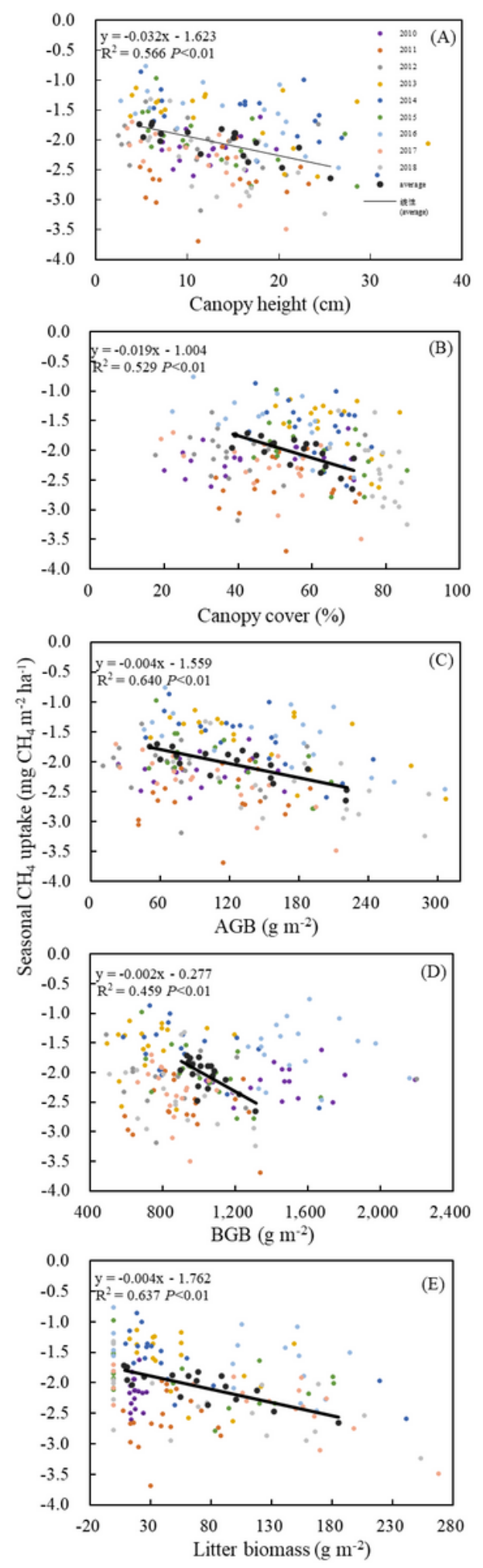

\section{Figure 5}

Empirical dependence of seasonal $\mathrm{CH} 4$ uptake on canopy height (A), canopy cove (B), aboveground biomass (C), belowground biomass (D), and litter biomass(E). 

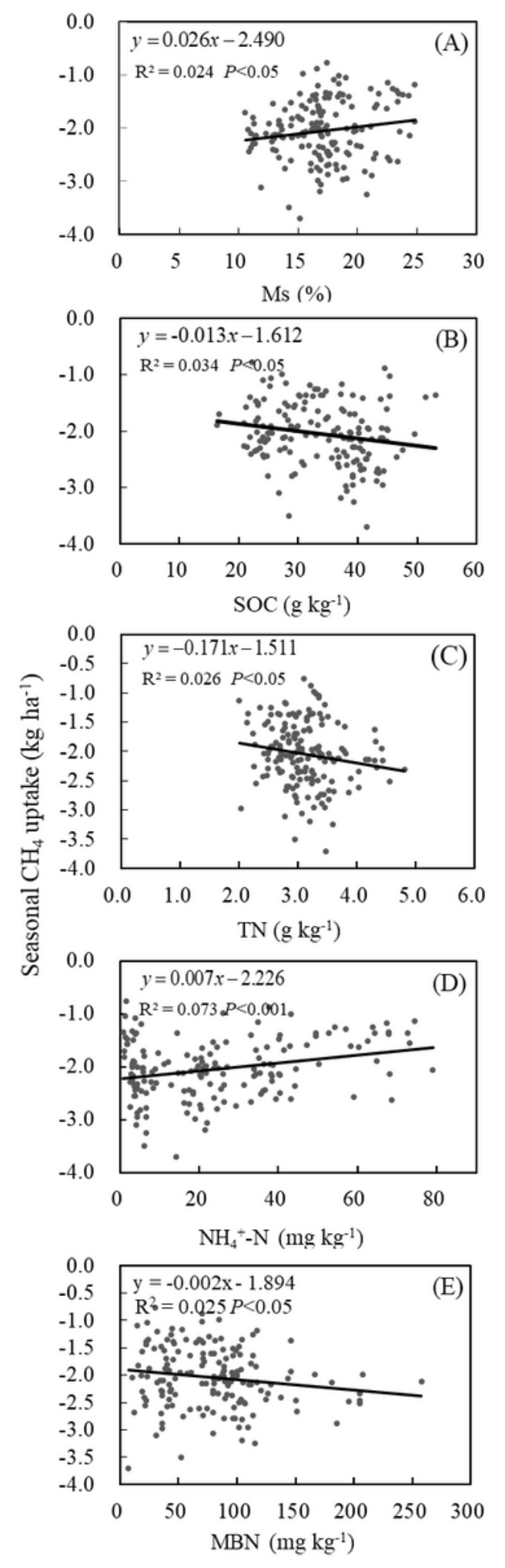

\section{Figure 6}

Empirical dependency of the seasonal $\mathrm{CH} 4$ uptake rate on soil moisture (A), soil carbon (B), total soil nitrogen (C), ammonium nitrogen (D), and soil microbial biomass nitrogen (E).

\section{Supplementary Files}


This is a list of supplementary files associated with this preprint. Click to download.

- floatimage7.jpeg 